\title{
STRATEGI PEMILIHAN JENIS TANAMAN UNTUK MENDUKUNG REHABILITASI PESISIR BERDASARKAN KARAKTERISTIK FISIK MAKRO DI MUARA SUNGAI PROGO (Strategy of Plant-Species Selection for Coastal Rehabilition Based on Macro-physical Characteristics in Progo Estuary)
}

\author{
Budiadi $^{1, *}$, Handojo Hadi Nurjanto ${ }^{1}$, Suryo Hardiwinoto ${ }^{1}$ dan Enggal Primananda ${ }^{2}$ \\ ${ }^{1}$ Bagian Silvikultur, Fakultas Kehutanan, Universitas Gadjah Mada, \\ Jl. Agro No. 1, Bulaksumur Yogyakarta 55281 \\ ${ }^{2}$ Program Pascasarjana, Fakultas Kehutanan, Universitas Gadjah Mada, \\ Jl. Agro No. 1, Bulaksumur, Yogyakarta 55281 \\ *Penulis korespondensi. Tel: 0274-550541. Email: budiadi@ugm.ac.id.
}

Diterima: 22 Desember 2015

Disetujui: 16 Mei 2016

\begin{abstract}
Abstrak
Muara Sungai Progo memiliki peran yang penting secara ekologis dan sosial-ekonomis bagi masyarakat Yogyakarta bagian selatan. Mengingat kondisinya kurang baik, maka dibutuhkan strategi rehabilitasi dengan jenis tanaman yang tepat. Penelitian ini bertujuan untuk memberikan arahan jenis tanaman yang sesuai untuk rehabilitasi pesisir muara Sungai Progo berdasarkan karakteristik fisik makro lahan. Penelitian ini menggunakan teknologi sistem informasi geografis (SIG) dengan metode digitasi dan overlay peta menggunkan software Arc GIS (ver. 10.0 ESRI) sebagai acuan analisis dan interpretasi peta kondisi muara selama 10 tahun terakhir, sehingga diketahui lokasi-lokasi yang tetap dari waktu ke waktu, dikombinasikan dengan pemetaan genangan air, salinitas dan sebaran jenis endapan. Lokasi penelitian adalah areal pasang surut yang relatif sempit (13,10 ha), namun berperan penting dalam rehabilitasi seluruh areal muara Sungai Progo (luas sekitar 100 ha). Berdasarkan kondisi ketergenangan air yang dipengaruhi arus yang lemah dan kadar salinitas, ditemukan relung-relung lahan basah yang sesuai untuk tanaman mangrove, terdiri dari lahan berpasir (2,49 ha) yang sesuai untuk jenis Avicennia marina, Rhizophora stylosa dan Ceriops tagal; serta berlumpur (0,89 ha) untuk jenis $R$. mucronata, $R$. apiculata, Bruguiera sp. dan Sonneratia alba. Pada lahan kering yang didominasi pasir (1,70 ha) direkomendasikan jenis Casuarina equisetifolia dan Pandanus tectorius; serta dominasi tanah (6,45 ha) dengan jenis produktif Callophyllum inophyllum dan kelapa. Dengan menanam jenis-jenis secara tepat dalam rehabilitasi jangka pendek, maka diharapkan akan berdampak baik pada rehabilitasi seluruh kawasan muara.
\end{abstract}

Kata kunci: kawasan pesisir, marjinal, mangrove, salinitas, sedimen.

\begin{abstract}
Progo estuary has an important ecological and socio-economic roles for communities in the South of Yogyakarta. Within a long time, the location is delayed in critical condition, and needs a proper rehabilitation strategy through selecting suitable species. The research aimed to recommend suitable species for coastal region of Progo estuary, based on study of macro-physycal characteristics of the site. The research conducted using GIS technology through digitation method and interpretation of map using Arc GIS (ver. 10.0 ESRI) fot the changes of Progo estuary in the last 10 years, determining the steady spots over time, and mapping wet areas, water salinity and distribution of the sediment. Research site is a small intertidal zone (13.10 ha), but plays important role to the whole rehabilitation program of Progo estuary (approximated $100 \mathrm{ha}$ ). Based on the mapping of wet area affected by slow wave and water salinity, it was determined niches of wet land that suitable for mangroves, consisted of sandy soil (2.49 ha) for Avicennia marina, Rhizophora stylosa and Ceriops tagal; and muddy soil (0.89 ha) for R. mucronata, R. apiculata, Bruguiera sp. and Sonneratia alba. On dry land dominated by sand (1.70 ha), the study recommends Casuarina equisetifolia and Pandanus tectorius; and on dry fertile soil with Callophyllum inophyllum and coconut. By planting the suitable species on the specific site, it will positively impacts on the rehabilitation program on the whole area of Progo estuary.
\end{abstract}

Keywords: coastal region, marginal land, mangrove, salinity, sediment.

\section{PENDAHULUAN}

Kawasan pesisir merupakan kawasan yang intensif dimanfaatkan untuk kegiatan manusia untuk pertambakan, pertanian, peternakan, pariwisata, industri dan lain-lain. Meskipun pemanfaatan daerah pesisir telah diatur dalam Undang-Undang Nomor 1 Tahun 2014 pasal 23 
ayat 1 (Anonim, 2014), namun aktivitas manusia untuk kepentingan ekonomi menjadi pemicu berkembangnya permasalahan yang makin kompleks. Pada era otonomi daerah, batas administrasi cenderung digunakan sebagai dasar dalam pengelolaan pesisir, padahal seharusnya pengelolaannya didasarkan pada batas ekosistem (Wibowo, 2002) dan dilakukan secara terpadu (Djunaedi dan Basuki, 2002).

Kawasan pesisir menjadi muara dari hasil erosi dan sedimentasi yang terjadi pada kawasan hulu akibat aliran air pada Daerah Aliran Sungai (DAS) tertentu. Erosi tanah mengakibatkan peningkatan kuantitas serta kecepatan sedimentasi, sehingga berakibat pada pendangkalan sungai, kerusakan habitat dan perubahan fungsinya. Kawasan mangrove sebagai kawasan peralihan merupakan lahan akumulasi endapan yang berperan penting untuk perlindungan pesisir. Aktivitas tambak yang dilakukan di lahan mangrove dan pantai dapat menghasilkan polusi dari limbah cair dan padat yang menyebabkan kondisi lahan semakin buruk, dan merupakan ancaman utama kelestarian ekosistem pesisir (Hamilton dkk., 1989; Primavera, 1998).

Sungai Progo merupakan bagian dari DAS Progo yang memiliki debit air terbesar di Daerah Istimewa Yogyakarta yang bermuara di Samudera Hindia, yakni di Desa Banaran, Kecamatan Galur, Kabupaten Kulonprogo. Muara Sungai Progo merupakan kawasan pelestarian sempadan pantai yang kondisinya kurang baik, yang rawan terhadap berbagai permasalahan lingkungan dan bencana alam, sehingga perlu direhabilitasi. Hal ini sesuai Peraturan Daerah Nomor 16 Tahun 2011 tentang Rencana Zonasi Wilayah Pesisir dan Pulau-pulau Kecil Daerah Istimewa Yogyakarta tahun 20112030 pasal 50 (b) tentang ketentuan pengembangan hutan di pesisir Kabupaten Bantul dan Kulonprogo (Anonim, 2013).

Untuk mendukung keberhasilan rehabilitasi lahan pesisir, maka perlu diperhatikan kondisi ekologi, status tapak, kondisi ekonomi dan sosial budaya (Sumardi, 2008; Hanley dkk., 2009). Untuk itu perlu strategi identifikasi faktor pembatas pada tapak lahan pesisir berupa kadar salinitas/kegaraman dan substrat endapan, menentukan jenis dan desain rehabilitasi dan rumusan ameliorasi tapak (Sumardi, 2008). Pada lahan mangrove, keberadaan endapan lumpur atau pasir merupakan faktor fisik yang penting untuk pertumbuhan tanaman, tetapi pertumbuhan terbaik umumnya pada substrat dasar lumpur (Hutching dan Saenger, 1987; Onrizal dan Kusmana, 2008). Pada lahan pantai berpasir di pantai Selatan, rehabilitasi dilakukan menggunakan cemara udang (Casuarina equisetifolia var. Incana), karena mampu memecah angin (wind break), beradaptasi terhadap tapak marginal, tahan terhadap salinitas dan kekeringan, berperakaran dalam, serta membentuk vegetasi rapat dan tinggi (Nurjanto dkk., 2009).

Mengingat besarnya tekanan kebutuhan manusia terhadap lahan pesisir, serta dampak bencana alam, maka upaya konservasi, rehabilitasi dan pembangunan jalur hijau hutan pantai merupakan kebutuhan yang mendesak (Goltenboth dkk., 2006). Pendekatan utama yang digunakan dalam kegiatan rehabilitasi adalah penanaman jenis-jenis yang sesuai dengan lahan pesisir. Untuk wilayah muara Sungai Progo, kajian tentang teknik rehabilitasi untuk lahan pantai dan mangrove belum pernah dilakukan, sehingga tidak ada acuan baku tentang jenis tanaman, pola tanam dan teknik silvikultur yang tepat (adaptable), dan dapat diterima oleh masyarakat (adoptable). Penelitian ini bertujuan untuk memetakan karakteristik fisik lahan berdasarkan kajian kestabilan kondisi sungai, dikombinasikan dengan kajian faktor-faktor makro yaitu kadar salinitas dan sebaran komposisi endapan tanah, untuk dijadikan acuan pemilihan spesies yang sesuai dan teknik rehabilitasi yang tepat.

\section{METODE PENELITIAN}

\section{Waktu dan Lokasi}

Penelitian ini dilakukan di kawasan pasang surut muara Sungai Progo (Gambar 1) yang merupakan perbatasan antara Kabupaten Kulonprogo dan Kabupaten Bantul. Secara administratif lokasi penelitian berada di Desa Banaran, Kecamatan Galur, Kabupaten Kulonprogo, D. I. Yogyakarta. Berdasarkan Keputusan Presiden No. 32 Tahun 1990 Tentang Pengelolaan Kawasan Lindung, muara Sungai Progo masuk dalam kategori kawasan suaka alam laut dan perairan lainnya.

Muara Sungai Progo memiliki kekhasan kondisi karena berhadapan dengan Samudera Hindia yang berombak besar, sekaligus merupakan lokasi sedimentasi hasil erupsi Gunungapi Merapi sehingga kondisi muara sungai berubah-ubah dari waktu ke waktu.

Lokasi penelitian merupakan wilayah pesisir yang relatif datar dan secara geomorfologis merupakan dataran aluvial, dengan ketinggian tempat antara 0-3 mdpl, suhu $25-29{ }^{\circ} \mathrm{C}$, dan ratarata curah hujan tahunan $1.907 \mathrm{~mm}$. Penelitian diawali dengan perencanaan dan survei awal (MeiJuni 2015), dan pengambilan data di lapangan dilakukan pada puncak musim kemarau (JuliAgustus 2015) yang merupakan saat pasang dan 


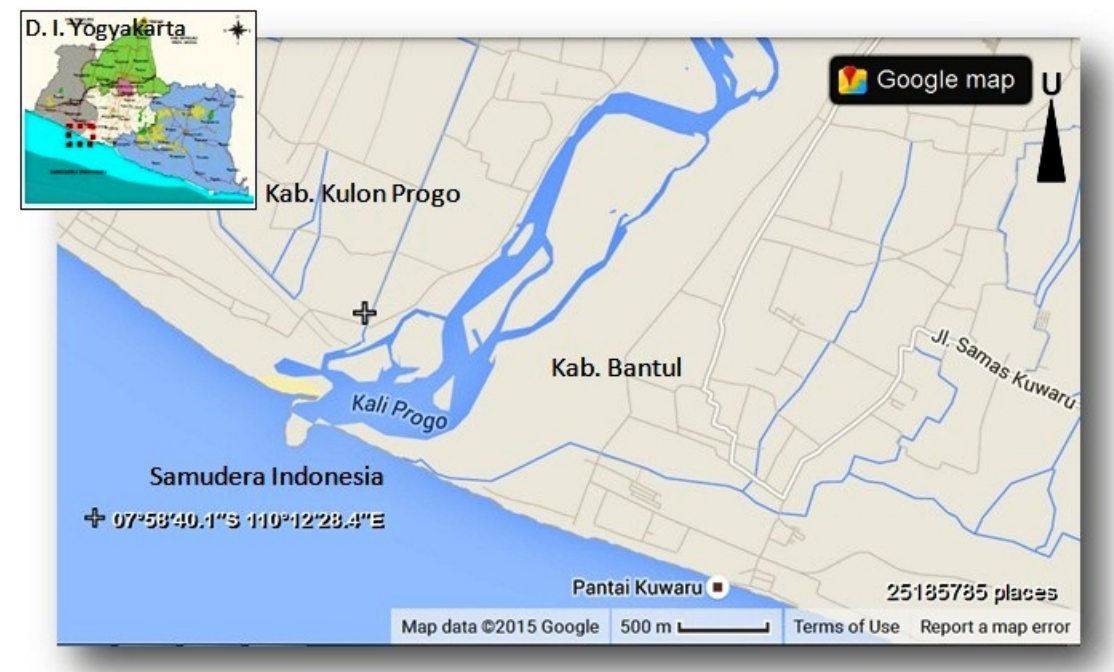

Gambar 1. Lokasi penelitian di muara Sungai Progo, wilayah Desa Banaran, Kecamatan Galur, Kabupaten Kulonprogo.

surut air laut terendah dalam satu tahun, agar diketahui batas bawah genangan pasang air laut.

\section{Prosedur Penelitian}

Penelitian ini menggunakan teknologi sistem informasi geografis (SIG). Pengolahan data mengunakan software Arc GIS (ver. 10.0 ESRI) dengan metode digitasi dan overlay yaitu menggabungkan peta citra satelit Google Earth (standar ISO-3166 yang diakui oleh divisi statistik PBB) (Sukri dan Yeni, 2016) dan peta hasil pengecekan langsung kondisi aktual di lapangan menggunakan GPS.

\section{Kajian perubahan kondisi muara}

Mengingat kondisi Sungai Progo yang berubah-ubah dari waktu ke waktu, maka kondisi tersebut harus dicermati untuk menentukan rencana tindakan rehabilitasi yang tidak terpengaruh oleh perubahan tersebut. Dalam kajian ini, perubahan lahan secara makro divisualisasikan dari citra satelit Google Earth dan diverifikasi dengan pengecekan kondisi aktual di lapangan, sehingga dapat dilakukan interpretasi peta untuk membandingkan perubahan kondisi muara dari waktu ke waktu, khususnya pada musim kemarau. Citra satelit Google Earth yang tersedia untuk musim kemarau dan digunakan untuk analisis adalah tanggal 11 Agustus 2006, 31 Mei 2009, 24 Agustus 2012 dan 13 Juni 2015. Dengan demikian, secara makro dapat diketahui titik-titik aman dan titik-titik kritis yang bisa dijadikan acuan untuk kegiatan rehabilitasinya.

\section{Kajian salinitas air}

Batas-batas genangan merupakan garis terluar air pasang yang mememungkinkan dilakukan rehabilitasi lahan dengan menggunakan spesies- spesies yang mampu beradaptasi dengan air payau (dalam hal ini jenis-jenis mangrove). Salinitas yang merupakan hasil percampuran air tawar dan air asin di kawasan pasang surut adalah salah satu faktor kimia yang menentukan pertumbuhan dan perkembangan hutan mangrove (Hutahaean dkk., 1999). Penentuan batas-batas terluar dilakukan pada puncak tertinggi pasang laut pada puncak musim kemarau (bulan purnama, bulan Juli atau Agustus). Garis terluar air pasang dipetakan dengan GPS sehingga diperoleh peta kondisi aktual batas air pasang yang kemudian dilakukan overlay terhadap citra satelit Google Earth menggunakan software Arc GIS (ver. 10.0 ESRI). Pada batasbatas terluar air pasang tersebut, ditentukan titiktitik pengambilan contoh air untuk diukur kegaraman/salinitas-nya dengan menggunakan hand refractometer.

\section{Kajian sebaran/distribusi endapan dan luas masing-masing}

Kajian sebaran/distribusi endapan dilaksanakan pada lahan yang relatif sempit, khususnya pada lahan peralihan darat dan laut, yang diprioritaskan menjadi lahan rehabilitasi dalam jangka pendek. Kajian ini merupakan pengecekan langsung di lapangan (ground check) dengan membuat titik-titik pengamatan setiap jarak $20 \mathrm{~m}$ di dalam dan di luar batas genangan air pasang (dari hasil pemetaan sebelumnya). Pada setiap titik, diamati dengan sidik cepat terhadap komposisi penyusun endapan (fraksi batu, pasir dan lumpur/tanah) dan digambarkan sebaran tersebut di atas peta dengan software Arc GIS (ver. 10.0 ESRI)

\section{Arahan pemilihan spesies untuk rehabilitasi}

Berdasarkan hasil-hasil penelitian, pengamatan dan pengukuran yang dikaji dari perubahan kondisi 
sungai, batas-batas genangan air pasang tertinggi, kadar salinitas dan sebaran jenis endapan, maka ditentukan arahan pemilihan jenis rehabilitasi dan luas lahan potensial dari masing-masing jenis yang direkomendasikan tersebut. Jenis-jenis tanaman pokok dikelompokkan menjadi tiga, yaitu tanaman mangrove secara umum, tanaman pantai, dan jenis tingkat tinggi lainnya untuk lahan pantai yang bermanfaat untuk masyarakat.

\section{HASIL DAN PEMBAHASAN}

\section{Perubahan Kondisi Sungai dari Waktu ke Waktu}

Muara Sungai Progo secara umum berubahubah karena faktor-faktor alam dan sosial yang mempengaruhinya. Seperti halnya muara-muara sungai di Pantai Selatan Jawa, muara Sungai Progo pada awalnya memiliki laguna yang menjorok ke arah barat (Gambar 2). Laguna bisa menjadi tempat tumbuh yang ideal tanaman mangrove, baik alami maupun tanaman karena tergenang oleh air payau, memiliki endapan lumpur untuk media tumbuh tanaman dan arus ombak yang tenang (Kusmana dkk., 2003). Namun demikian, laguna tersebut berangsur-angsur menyempit dan menghilang, terutama dipengaruhi oleh endapan hasil erupsi Gunungapi Merapi tahun 2006 dan 2010. Pada citra satelit tahun 2012 dan 2015, laguna Sungai Progo sudah tertutup sama sekali, dan sisa lahan tersebut digunakan untuk lahan tambak udang yang semakin meluas.

Pada bagian lain, terjadi pergeseran sungai pada bagian atas muara. Sungai pada bagian ini pada awalnya berimpit dengan tanggul Desa Banaran (citra satelit tahun 2006 dan 2010), pada wilayah Kulonprogo. Sungai bergeser menjauh dari tanggul desa ke arah Bantul (citra satelit tahun 2012 dan 2015). Hal ini antara lain disebabkan oleh endapan erupsi Gunung Merapi yang besar yakni material lahar dingin akan membantu terbentuknya tanah dari bahan erupsi (Rahayu dkk., 2014), serta aktivitas penambangan pasir pada wilayah Kabupaten Bantul. Akibatnya, lahan garapan milik petani di wilayah Kulonprogo meluas.

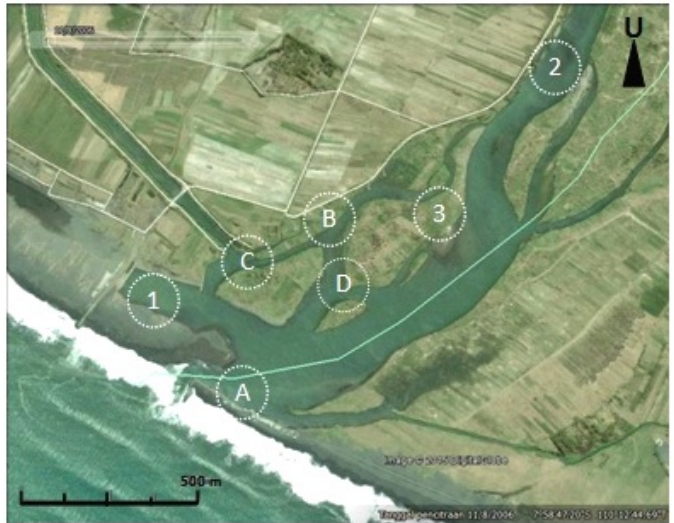

Keadaan sungai tahun 2006

(a)

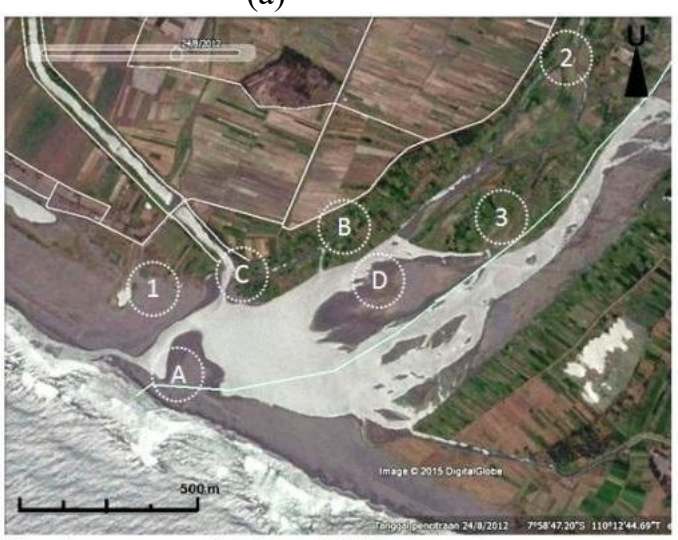

Keadaan sungai tahun 2012

(c)

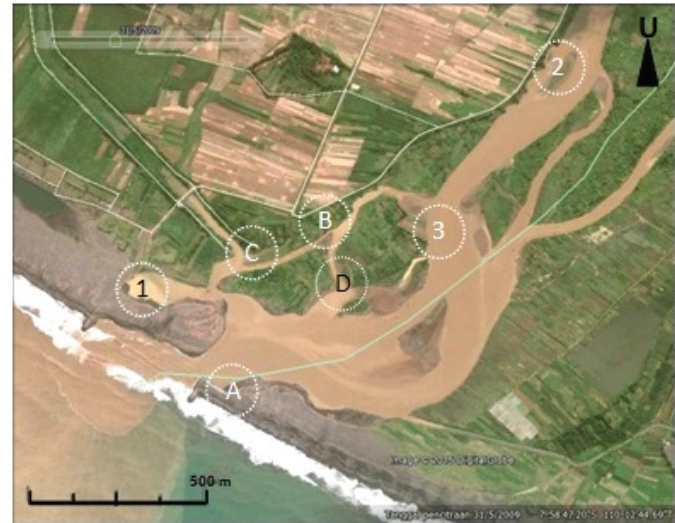

Keadaan sungai tahun 2009

(b)

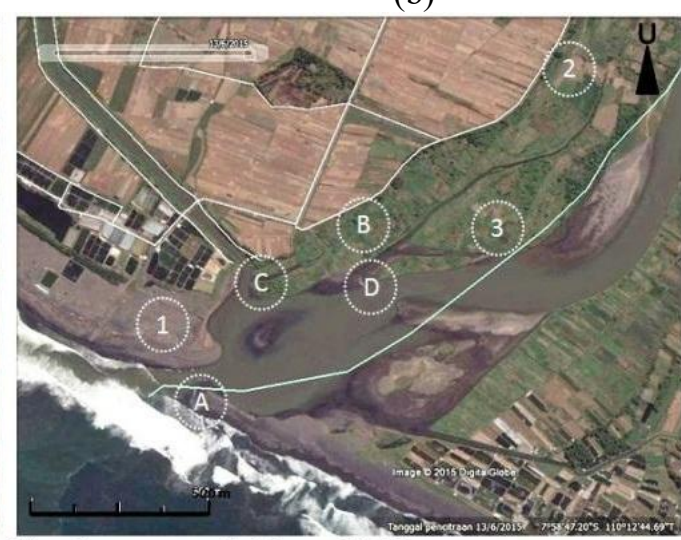

Keadaan sungai tahun 2015

(d)

Gambar 2. Perubahan-perubahan kondisi muara sungai Progo berdasarkan citra satelit Google Earth pada musim kemarau tahun 2006, 2010, 2012 dan 2015 (keterangan gambar secara detail tersaji pada Tabel 1). 
Tabel 1. Kondisi muara Sungai Progo yang berubah (kode 1-3) dan tetap (kode A-D) dari waktu ke waktu.

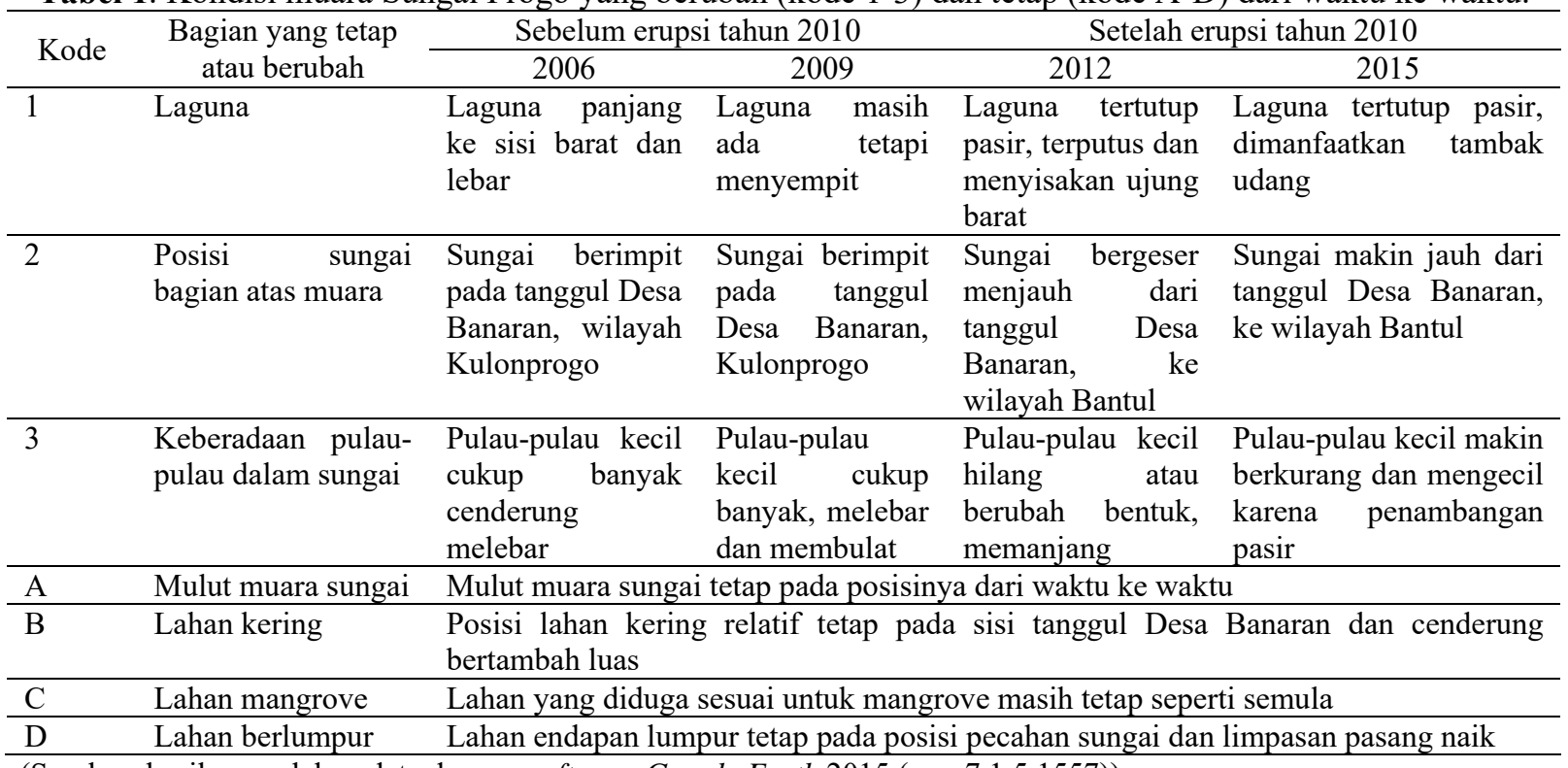

(Sumber: hasil pengolahan data dengan software Google Earth 2015 (ver. 7.1.5.1557))

Kondisi sungai yang berubah-ubah karena pengaruh besarnya volume endapan dan aktivitas lainnya membentuk daratan pulau-pulau kecil di sepanjang aliran sungai. Pulau-pulau tersebut pada musim kemarau dimanfaatkan untuk budidaya rumput pakan ternak oleh masyarakat Desa Banaran, namun pada musim hujan tergenang air secara terus menerus. Ukuran, bentuk dan kondisi pulau-pulau tersebut cenderung berubah dari waktu ke waktu. Pada umumnya, sebelum tahun 2010 pulau-pulau di dalam sungai cenderung luas dan membulat, setelah tahun 2010 mengecil, menyempit dan memanjang. Dinamika kondisi muara Sungai Progo tersaji pada Tabel 1.

Meskipun terjadi perubahan-perubahan kondisi sungai, namun terdapat bagian-bagian di sekitar muara sungai yang relatif tetap selama 10 tahun terakhir. Kondisi yang tetap tersebut terdiri dari: mulut muara sungai yang tidak bergeser (Lahan A), lahan kering yang terdapat pada sisi tanggul Desa Banaran tetap atau bertambah luas (Lahan B), lahan yang sesuai untuk mangrove relatif tetap pada sisi barat muara sungai (Lahan C), dan terdapat akumulasi endapan pasir dan lumpur pada lahan basah seiring perubahan ukuran dan bentuk pulau-pulau kecil (Lahan D). Endapan yang terakumulasi pada posisi lahan $\mathrm{C}$ dan $\mathrm{D}$ merupakan akibat dari arus pasang yang lemah dan tenang. Dengan adanya kondisi-lokasi yang tetap dari waktu ke waktu, ditambah dengan pertimbangan faktor-faktor penggenangan air pasang, kadar salinitas air, serta jenis dan komposisi endapannya, maka kegiatan rehabilitasi bisa diarahkan dengan menyeleksi jenis tanaman yang tepat pada masingmasing variasi kondisi tapak tersebut.

\section{Kajian Salinitas Air}

Titik-titik pengambilan sampel air untuk pengukuran kadar salinitas yang mewakili lokasi terluar genangan pada kondisi pasang air laut optimum (yang terjadi saat periode bulan purnama, tanggal 15 pada Kalender Jawa) ditunjukkan pada Gambar 3. Genangan air pasang pada puncak musim kemarau/kering pada saat bulan purnama pasang air laut masih cukup luas. Tingginya genangan akibat pasang air laut akan mempengaruhi tingkat salinitas (Nybakken, 1992).

Pada saat pasang, pulau-pulau kecil di dalam sungai tenggelam dan saat surut pulau-pulau tersebut muncul kembali. Lama waktu terjadinya pasang dan frekuensi genangan air di muara sungai dapat mempengaruhi perubahan salinitas air, di mana salinitas akan meningkat pada saat pasang dan sebaliknya akan menurun pada saat air laut surut.

Tabel 2 menunjukkan hasil pengukuran salinitas air pada titik-titik sampel di muara Sungai Progo saat periode pasang tertinggi bulan purnama, dengan variasi kadar salinitas terendah 6,2 $\pm 0,4$ ppm dan tertinggi 25,2 $\pm 0,4 \mathrm{ppm}$. Kondisi salinitas masih dalam batas kesesuaian baku mutu air laut untuk budidaya mangrove di DIY yaitu sampai dengan 34 ppm (Anonim, 2010), dan menjadi daya dukung rehabilitasi mangrove di muara Sungai Progo.

Dari 25 titik tersebut diklasifikasikan menjadi tiga tingkatan salinitas yaitu $0-10 \mathrm{ppm}$ (delapan titik), $>10-20 \mathrm{ppm}$ (13 titik) dan $>20 \mathrm{ppm}$ (empat titik). Tidak ada hubungan yang jelas antara jarak dengan bibir pantai dengan variasi kadar salinitas tersebut. Titik o dan $\mathrm{p}$ merupakan titik yang 
jaraknya jauh yaitu sekitar $900 \mathrm{~m}$ dari bibir pantai memiliki kadar salinitas yang tinggi ( $>20 \mathrm{ppm})$. Hal ini terjadi karena air laut yang pasang membawa garam dan garam terjebak di lokasi tersebut, karena titik-titik tersebut tidak dilalui aliran air tawar/ sungai. Pada titik d dan e dengan jarak yang lebih dekat yaitu sekitar $300 \mathrm{~m}$ diperoleh kadar salinitas yang lebih rendah yaitu $>10-20$ ppm, karena dilalui aliran sungai/air tawar.

Kadar salinitas pada semua titik pengamatan merupakan kisaran salinitas yang baik untuk pertumbuhan mangrove, karena tumbuhan mangrove merupakan spesies yang toleran terhadap salinitas tinggi dibandingkan spesies lain. Tanaman mangrove dapat hidup di perairan payau yang memiliki kisaran salinitas sepanjang tahun antara 435 ppt (Djohan, 2010), dan tumbuh subur pada kisaran salinitas 10-30 ppt (Kusmana dkk., 2003), serta kurang baik pada salinitas yang sangat tinggi atau ekstrim (Supriharyono, 2000).

\section{Kajian Sebaran/Distribusi Endapan dan Luas Masing-Masing}

Dalam penelitian ini pengamatan terhadap sebaran jenis endapan dilakukan dengan cara sidik cepat kemudian dipetakan dalam wujud distribusi sebaran dan luasannya. Hasil pemetaan sebaran jenis endapan di muara Sungai Progo disajikan pada Gambar 4. Kelompok jenis endapan pada lahan kering dan basah terdiri dari tiga kategori

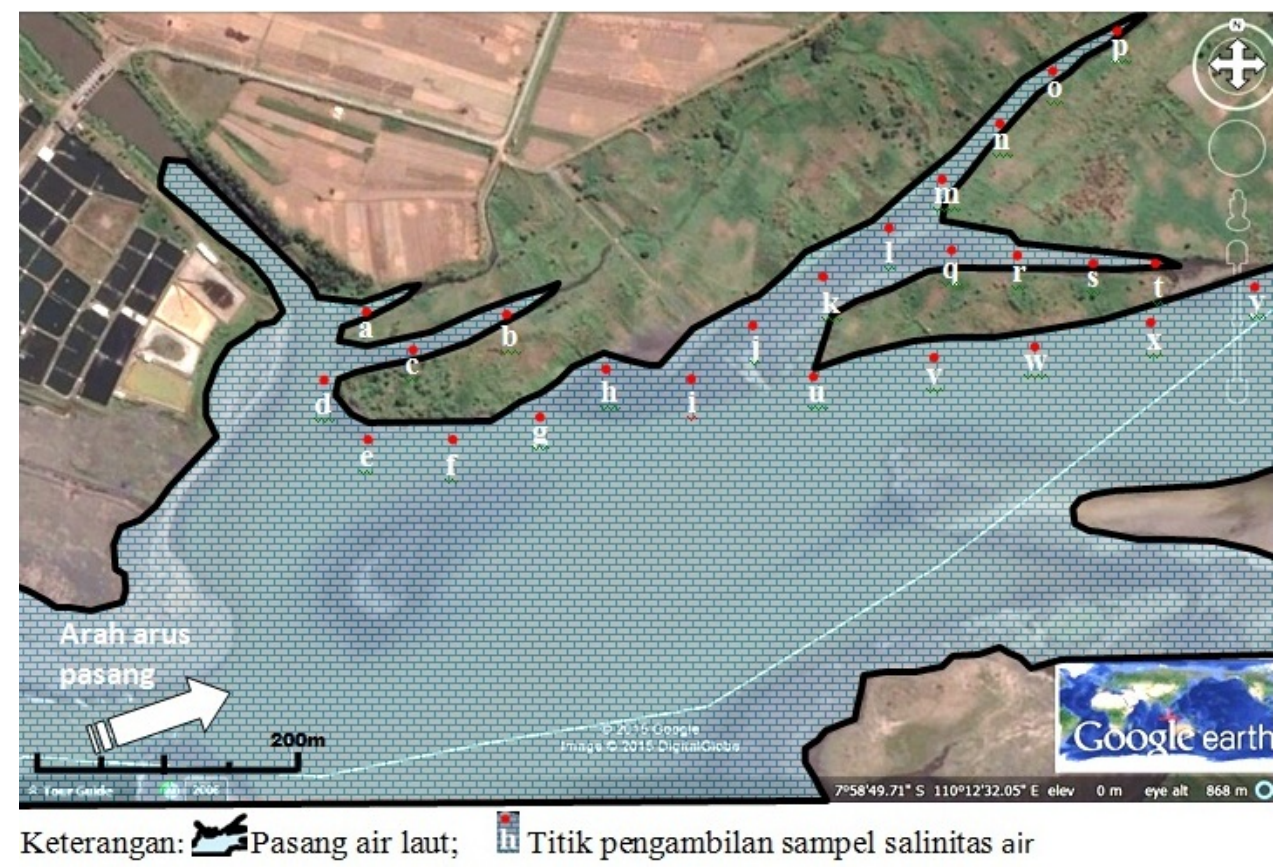

Gambar 3. Sebaran lokasi pengambilan sampel air untuk analisis salinitas di muara Sungai Progo (data sebaran nilai salinitas pada Tabel 2).

Tabel 2. Variasi salinitas air di muara Sungai Progo berdasarkan jarak dari pantai

\begin{tabular}{|c|c|c|c|c|c|c|c|c|}
\hline \multicolumn{3}{|c|}{ Salinitas $0-10 \mathrm{ppm}$} & \multicolumn{3}{|c|}{ Salinitas $>10-20 \mathrm{ppm}$} & \multicolumn{3}{|c|}{ Salinitas $>20 \mathrm{ppm}$} \\
\hline Titik & $\begin{array}{l}\text { Jarak dari } \\
\text { pantai }(\mathrm{m})\end{array}$ & $\begin{array}{l}\text { Salinitas } \\
\text { faktual (ppm) }\end{array}$ & Titik & $\begin{array}{l}\text { Jarak dari } \\
\text { pantai }(\mathrm{m})\end{array}$ & $\begin{array}{l}\text { Salinitas } \\
\text { faktual (ppm) }\end{array}$ & Titik & $\begin{array}{l}\text { Jarak dari } \\
\text { pantai }(\mathrm{m})\end{array}$ & $\begin{array}{l}\text { Salinitas } \\
\text { faktual (ppm) }\end{array}$ \\
\hline $\mathrm{a}$ & 433 & $10,0 \pm 0,0$ & $\mathrm{~b}$ & 508 & $19,0 \pm 0,0$ & $\mathrm{c}$ & 430 & $25,2 \pm 0,4$ \\
\hline $\mathrm{s}$ & 913 & $9,8 \pm 0,4$ & d & 366 & $17,6 \pm 0,5$ & $\mathrm{i}$ & 567 & $21,0 \pm 0,0$ \\
\hline $\mathrm{t}$ & 954 & $9,2 \pm 0,4$ & $\mathrm{e}$ & 357 & $17,0 \pm 0,0$ & o & 920 & $21,8 \pm 0,4$ \\
\hline $\mathrm{u}$ & 664 & $7,0 \pm 0,0$ & $\mathrm{f}$ & 403 & $17,0 \pm 0,7$ & $\mathrm{p}$ & 970 & $20,8 \pm 0,4$ \\
\hline $\mathrm{v}$ & 752 & $7,0 \pm 0,0$ & $\mathrm{~g}$ & 463 & $17,2 \pm 0,8$ & & & \\
\hline $\mathrm{W}$ & 827 & $7,0 \pm 0,0$ & $\mathrm{~h}$ & 522 & $20,0 \pm 0,0$ & & & \\
\hline $\mathrm{x}$ & 910 & $7,0 \pm 0,0$ & $\mathrm{j}$ & 629 & $16,0 \pm 0,0$ & & & \\
\hline $\mathrm{y}$ & 990 & $6,2 \pm 0,4$ & $\mathrm{k}$ & 703 & $15,8 \pm 0,4$ & & & \\
\hline & & & 1 & 755 & $15,2 \pm 0,4$ & & & \\
\hline & & & $\mathrm{m}$ & 824 & $15,8 \pm 0,4$ & & & \\
\hline & & & $\mathrm{n}$ & 874 & $20,0 \pm 0,0$ & & & \\
\hline & & & $q$ & 811 & $18,2 \pm 0,4$ & & & \\
\hline & & & $\mathrm{r}$ & 866 & $11,0 \pm 0,0$ & & & \\
\hline
\end{tabular}

Sumber: diolah dari data primer hasil pengukuran langsung tahun 2015. 


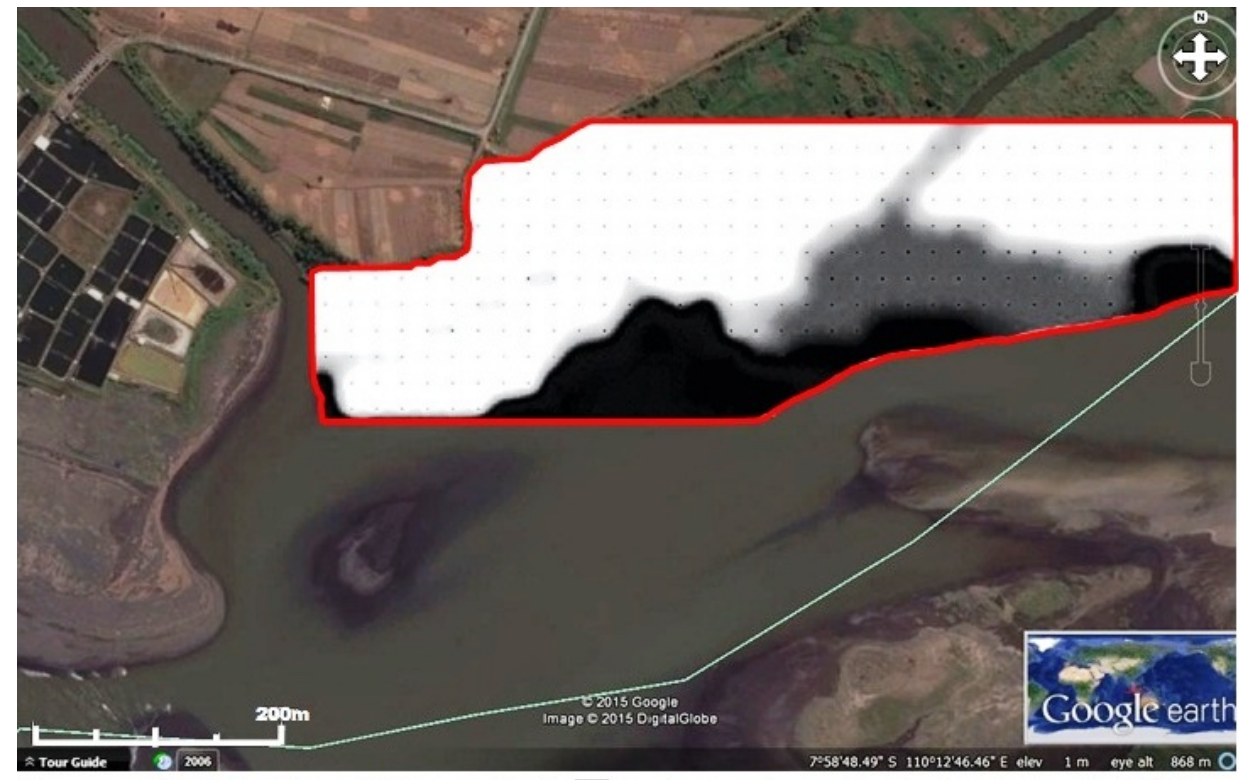

Keterangan: DLokasi riset; •Titik groundcheck; $\square$ Dominasi tanah; Dominasi pasir; $\square$ Kerikil \& batu Gambar 4. Sebaran jenis endapan di muara Sungai Progo.

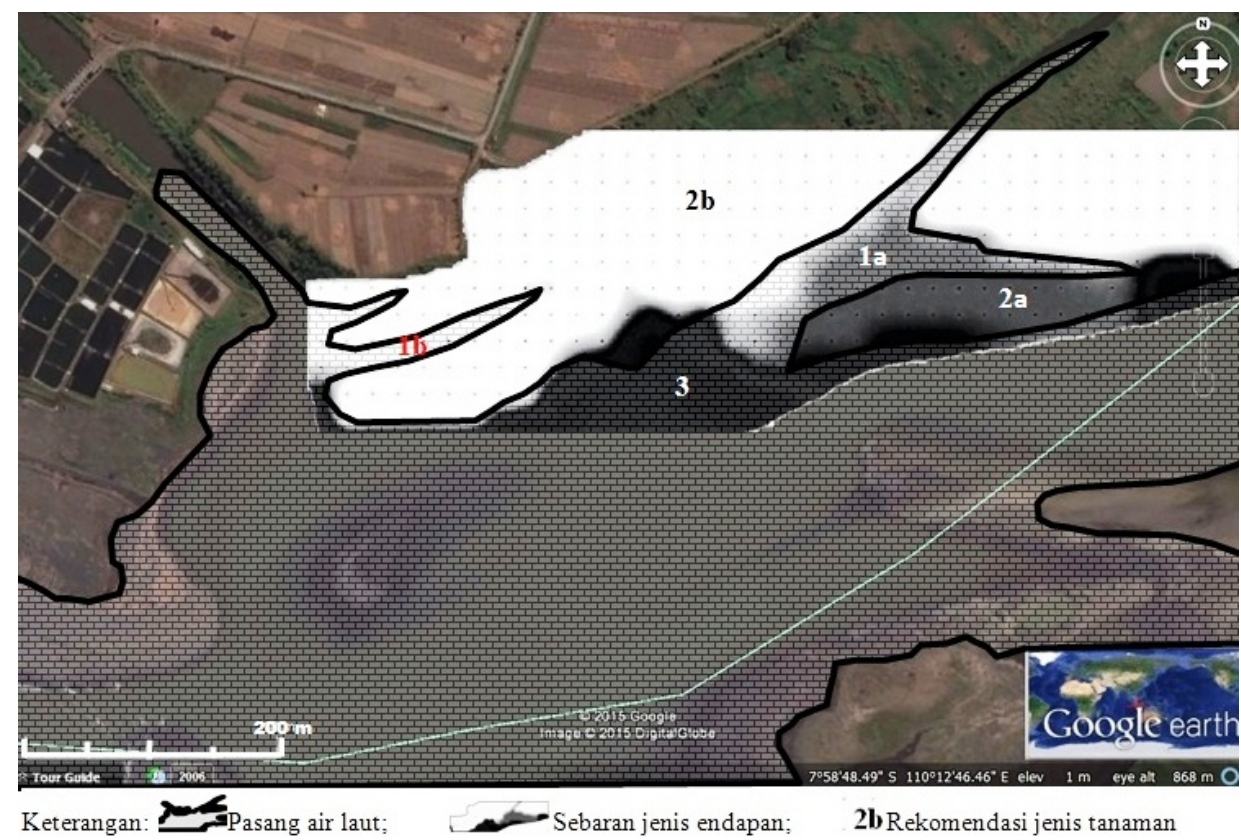

Gambar 5. Arahan pemilihan jenis tanaman dan penempatannya sesuai kajian fisik makro lahan di muara Sungai Progo (keterangan jenis tersaji pada Tabel 4).

Tabel 3. Luas lahan berdasarkan jenis endapan di muara Sungai Progo.

\begin{tabular}{lll}
\hline No & Jenis endapan & Luas (ha) \\
\hline 1 & Dominasi tanah & 7,32 \\
2 & Dominasi pasir & 4,19 \\
3 & Kerikil dan batu & 1,59 \\
& Jumlah & 13,10 \\
\hline
\end{tabular}

Sumber: diolah dari data primer tahun 2015.

yaitu warna putih menunjukkan endapan dengan dominasi tanah, warna abu-abu (dominasi pasir) dan warna hitam (endapan kerikil dan batu). Pada lahan kering banyak didominasi oleh endapan tanah sedangkan pada lahan basah didominasi endapan pasir hingga kerikil-batu. Data tersebut sesuai dengan Laporan SLHD (Anonim, 2012) bahwa semua pantai di Kabupaten Bantul dan Kulonprogo merupakan bentukan asal fluvial yaitu dataran pantai yang landai dan tersusun atas endapan sedimen yang belum terkonsolidasi seperti debu, lumpur, pasir dan kerikil, membentuk ekosistem gumuk pasir, mangrove dan hutan cemara laut.

Variasi jenis endapan merupakan sumber nutrien di ekosistem hutan mangrove dan pantai, 
Tabel 4. Arahan pemilihan jenis tanaman padalahan potensial di muara Sungai Progo berdasarkan karakteristik makro.

\begin{tabular}{|c|c|c|c|}
\hline No. & Karakteristik makro lahan & Luas area (ha) & Jenis tanaman yang direkomendasikan \\
\hline \multirow[t]{8}{*}{1} & Lahan tergenang air pasang & & \\
\hline & 1.a. Dominasi pasir & 2,49 & - Api-api (Avicennia marina) \\
\hline & & & - Rhizophora stylosa \\
\hline & & & - Ceriops tagal \\
\hline & 1.b. Dominasi lumpur & 0,87 & - Rhizophora mucronata \\
\hline & & & - Rhizophora apiculata \\
\hline & & & - Tancang (Bruguiera sp.) \\
\hline & & & - Sonneratia alba \\
\hline \multirow[t]{5}{*}{2} & Lahan kering & & \\
\hline & 2.a. Dominasi pasir & 1,70 & - Cemara udang (Casuarina equisetifolia) \\
\hline & & & - Pandan (Pandanus tectorius) \\
\hline & 2.b. Dominasi tanah & 6,45 & - Nyamplung (Callophyllum iniphyllum) \\
\hline & & & - Kelapa (Cocos nucifera) \\
\hline \multirow[t]{2}{*}{3} & Lahan berbatu dan kerikil & 1,59 & (Tidak bisa ditanami) \\
\hline & Total & 13,10 & \\
\hline
\end{tabular}

(Sumber: diolah dari data primer tahun 2015)

sehingga mempengaruhi kesesuaian jenis tanaman. Sedimen yang mengendap di muara Sungai Progo yang berhulu di Gunung Merapi, didominasi oleh pasir vulkanik yang banyak mengandung unsur hara bagi pertumbuhan tanaman. Agregat butir tanah yang mudah terurai oleh air menyebabkan tanah menjadi berlumpur. Kedua kelompok endapan dibawa oleh aliran sungai ke laut, dan oleh arus pasang surut sedimen tersebut dibawa kembali ke pantai dan ditangkap kemudian diendapkan (Kamaruzzaman dkk., 2001) membentuk pola distribusi endapan yang khas baik yang tergenang (payau) maupun yang kering.

Tabel 3 menunjukkan luas area hasil pemetaan jenis endapan pada lokasi penelitian pada lahan pesisir di muara Sungai Progo. Luas area yang dipengaruhi langsung pasang surut air laut yaitu 13,10 ha, terdiri dari tiga kelompok jenis endapan yaitu dominasi tanah seluas 7,32 ha; dominasi pasir 4,19 ha; serta kerikil dan batu 1,59 ha.

Area tersebut menjadi prioritas utama rehabilitasi jalur hujau kawasan pesisir dalam jangka pendek. Menurut peraturan perlindungan jalur hijau nasional bahwa batasan jalur hijau kawasan pesisir yaitu selebar 100-200 m di sepanjang pantai, namun jarak yang tepat tergantung pada kemampuan air pasang mencapai tepi pantai (Hanley dkk., 2009). Lokasi terluar atau batas pasang terjauh dari penelitian ini mencapai jarak sekitar $900 \mathrm{~m}$ dari bibir pantai, karena lahan relatif datar dengan tingkat elevasi sekitar 0-2 mdpl.

\section{Arahan Pemilihan Spesies untuk Rehabilitasi}

Untuk memilih jenis yang sesuai dalam relung-relung (niche) di pesisir muara Sungai Progo, dengan berdasarkan kajian fisik kestabilan kondisi lahan, ketergenangan air dengan arus yang lemah, kadar salinitas, dan komposisi endapan tanah secara makro, maka kelompok jenis tanaman yang direkomendasikan disajikan pada Gambar 5, dan perincian karakteristik makro lahan, luas masing-masing serta jenis yang direkomendasikan pada Tabel 4.

Arahan pemilihan jenis untuk rehabilitasi muara Sungai Progo ini merupakan hasil studi pada lahan prioritas jangka pendek (lima tahun ke depan) sehingga tidak luas, namun akan sangat menentukan keberhasilan rehabilitasi seluruh kawasan muara Sungai Progo jangka panjang yang diperkirakan lebih dari 100 ha.

Pada kawasan muara, delta dan lahan payau, jenis-jenis mangrove secara alami sebenarnya bisa membentuk zonasi-zonasi yang jelas (Muhsin dan Indrawati, 2008). Namun demikian, di wilayah muara Sungai Progo zonasi-zonasi tersebut tidak terbentuk karena faktor-faktor alam misalnya ombak yang besar dan endapan sungai yang didominasi oleh material berpasir. Lahan yang sesuai untuk mangrove tersebar pada kelompokkelompok kecil pada relung-relung, yaitu tapak yang spesifik dengan ukuran relatif kecil yang basah dan didominasi endapan tanah atau lumpur (Setyawan dkk., 2002).

Sifat fisik dan kimia suatu habitat mangrove yang didalamnya termasuk tipe tanah, genangan air, kekuatan ombak dan kadar salinitas air merupakan pertimbangan utama dalam upaya rehabilitasi dan pemilihan jenis mangrove (Poedjirahajoe, 2007; Martuti, 2013). Berdasarkan kajian kadar salinitas air pasang yang menggenangi lahan muara Sungai Progo, dapat disimpulkan bahwa semua titik pengamatan merupakan lahan dengan kadar garam yang sesuai untuk semua jenis mangrove, yaitu 4 - 
35 ppm (Djohan, 2010). Selanjutnya, pada lahan payau tersebut ditentukan jenis mangrove yang sesuai berdasarkan relung-relung yang terbentuk karena endapan secara makro, yang dipilah menjadi lahan dengan dominasi pasir seluas 2,49 ha dan dominasi lumpur seluas 0,87 ha. Mengacu pada Setyawan dkk. (2002); Kusmana dkk. (2003); dan Wahyuningsih dkk. (2012), maka pada lahan dominasi pasir direkomendasikan jenis api-api (Avicennia marina), Rhizophora stylosa dan Ceriops tagal, sedangkan pada lahan dominasi lumpur dengan jenis $R$. mucronata, $R$. apiculata, Bruguiera sp. dan Sonneratia alba. Jenis-jenis mangrove ini sesuai dengan sebaran mangrove di pesisir Selatan D. I. Yogyakarta yang sebelumnya telah tumbuh pada hutan buatan seluas 5,0 ha di Baros (Kabupaten Bantul) dan 124,9 ha di Pasirmendit, Jangkaran (Kabupaten Kulonprogo) (Anonim, 2012).

Sebaran endapan dalam jangka waktu yang lalu juga menghasilkan lahan kering di muara Sungai Progo. Jika diklasifikasikan berdasarkan komposisi makro tanah, lahan kering pun menghasilkan relung-relung yang terdiri dari lahan dominasi pasir dan tanah. Pada lahan pasir, dengan kondisinya yang kering pada musim kemarau, maka jenis tanaman yang direkomendasikan adalah jenis pionir pantai yaitu cemara udang (Casuarina equisetifolia) (Nurjanto dkk., 2009; Nugroho, 2013) dan pandan laut (Pandanus tectorius). Kombinasi Pandanus dan C. equisetifolia dianjurkan sebagai vegetation bioshield untuk melindungi daerahdaerah pesisir dari dampak bahaya tsunami (Thuy dkk., 2012). Tanaman pionir ini perlu ditanam di tepi-tepi sungai dan pantai pada lahan seluas 1,70 ha, yang fungsi utamanya untuk meningkatkan kelembaban tanah, pemecah angin (wind break), menurunkan kadar garam udara dan meningkatkan kesuburan tanah (Suhardi dkk., 2002; Singh dkk., 2011). Lahan kering yang didominasi tanah merupakan lahan-lahan yang subur, sehingga lebih fleksibel dalam pemilihan jenis, namun keberhasilannya ditentukan oleh keberadaan tanaman pemecah angin. Pada saat ini hampir tidak ada tanaman produktif yang ditanam pada pada lahan kering yang luas di muara Sungai Progo. Sebagai awal kegiatan rehabilitasi pada lahan seluas 6,45 ha, maka direkomendasikan untuk dipilih tanaman-tanaman asli pantai yang produktif dan sesuai aspirasi masyarakat (Hanley dkk., 2009), yaitu nyamplung (Callophyllum inophyllum) dan kelapa (Cocos nucifera). Nyamplung merupakan tanaman yang potensial sebagai penghasil buah untuk obat, bioenergi danbahan minyak nabati (Mile, 2007; Hadi, 2009; Prabakaran dan Britto, 2012). Tanaman kelapa adalah tanaman pantai serbaguna dan memasyarakat, yang dipergunakan untuk kepentingan sehari-hari maupun sebagai sumber pendapatan tambahan.

Jenis-jenis usulan pada lahan pesisir di atas sudah mempertimbangkan karakter fisiologis tanaman yaitu toleransi terhadap khususnya kadar salinitas dan genangan air. Menurut Goltenboth dkk. (2006), jenis-jenis tanaman pesisir memiliki kutikula (baik dari ketebalan maupun lapisan lilinnya), yang berfungsi untuk mengurangi masuknya garam ke tubuh tanaman, serta memiliki kemampuan beradaptasi dengan kondisi evaporasi yang tinggi, misalnya Callophyllum sp., Terminalia cattapa dan Barringtoniasp.

\section{KESIMPULAN}

Belum adanya arahan tentang teknik rehabilitasi muara Sungai Progo dikhawatirkan akan semakin meningkatkan resiko lingkungan bagi masyarakat Yogyakarta bagian Selatan. Melalui penelitian ini telah dipetakan perubahan-perubahan kondisi sungai selama sekitar 10 tahun, dan diketahui lokasi-lokasi yang tetap dari waktu ke waktu sebagai lahan yang siap direhabilitasi dalam jangka pendek. Lokasi penelitian adalah areal pasang surut yang relatif sempit $(13,10 \mathrm{ha})$, namun menjadi kunci keberhasilan rehabilitasi seluruh areal lahan muara Sungai Progo (seluas sekitar 100 ha).

Berdasarkan kondisi ketergenangan air dengan arus yang lemah dan kadar salinitas, ditemukan relung-relung lahan basah yang sesuai untuk tanaman mangrove, terdiri dari lahan berpasir $(2,49$ ha) untuk jenis Avicennia marina, Rhizophora stylosa dan Ceriops tagal; serta berlumpur $(0,89$ ha) untuk jenis $R$. mucronata, $R$. apiculata, Bruguiera sp. dan Sonneratia alba. Selain itu pada lahan kering yang didominasi pasir $(1,70 \mathrm{ha})$ direkomendasikan jenis Casuarina equisetifolia dan Pandanus tectorius, serta dominasi tanah (6,45 ha) dengan jenis produktif seperti Callophyllum inophyllum dan kelapa. Dengan menempatkan jenis-jenis tersebut secara tepat dalam rehabilitasi jangka pendek, maka diharapkan akan berdampak baik pada rehabilitasi seluruh kawasan muara.

\section{DAFTAR PUSTAKA}

Anonim, 2010. Baku Mutu Air Laut. Yogyakarta. Anonim, 2012. Badan Lingkungan Hidup, Provinsi D.I. Yogyakarta. Yogyakarta.

Anonim, 2013. Rencana Kerja Pembangunan Daerah Tahun 2014. Pemerintah Daerah Provinsi Daerah Istimewa, Yogyakarta 
Anonim, 2014. Perubahan Atas Undang-Undang Nomor 27 Tahun 2007 Tentang Pengelolaan Wilayah Pesisir dan Pulau-Pulau Kecil. Jakarta.

Djohan, T.S., 2010. Dinamika Kualitas PlanktonDi Perairan Ekosistem Hutan Bakau Segara Anakan yang Sedang Berubah. Jurnal Manusia dan Lingkungan, 17(3):135-149

Djunaedi, A., dan Basuki, M.N., 2002. Perencanaan Pengembangan Kawasan Pesisir. Jurnal Teknologi Lingkungan, 3(3):225-231.

Goltenboth, F., Timotius, K.H., Milan, P.P., dan Margraf, J., 2006. Ecology of Insular Southeast Asia. The Indonesian Archipelago. Elsevier. Amsterdam.

Hadi, W.A., 2009. Pemanfaatan Minyak Biji Nyamplung (Calophylluminophyllum L.) sebagai Bahan Bakar Minyak Pengganti Solar. Jurnal Riset Daerah, 8(2):1044-1052.

Hamilton, L., Dixon, J., and Miller, G., 1989. Mangroves: An Undervalued Resource of The Land and The Sea. Ocean Yearbook, 8:254288.

Hanley, R., Mamonto, D., dan Broadhead, J., 2009. Petunjuk Rehabilitasi Hutan Pantaiuntuk Wilayah Provinsi Aceh dan Sumatera Utara. FAO Regional Office for Asia and the Pacific. Bangkok.

Hutahaean, E., Kusmana, C., dan Dewi, H.R., 1999. Studi Kemampuan Tumbuh Anakan Mangrove Jenis Rhizophora mucronata, Bruguiera Gimnorrhiza dan Avicennia marina pada Berbagai Tingkat Salinitas. Jurnal Manajemen Hutan Tropika, 5(1):77-85

Hutching, P., dan Saenger, P., 1987. Ecology of Mangrove. University of Queensland Press. ST Lucia.

Kamaruzzaman, B.Y., Mohd-Lokman, H. , Sulong, I., dan Razanudin, I., 2001. Sedimentation Rates on the Mangrove Forests of Pulau Che Wan Dagang, Kemaman Terengganu. The Malaysian Forester, 64(1):6-13.

Kusmana, C., Wilarso, S., Hilwan, I., Pamoengkas, P., Wibowo, C., Tiryana, T., Triswanto, A., dan Hamzah Y., 2003. Teknik Rehabilitasi Mangrove. Fakultas Kehutanan Institut Pertanian Bogor. Bogor.

Martuti, N.K.T., 2013. Keanekaragam Mangrove di Wilayah Tapak, Tugurejo, Semarang. Jurnal Mipa 36(2):123-130.

Mile, M.Y., 2007. Pengembangan Species Tanaman Pantai untuk Rehabilitasi dan Perlindungan Kawasan Pantai Pasca Tsunami. Info Teknis, 5(2):1-8.

Muhsin, dan Indrawati, 2008. Distribusi dan Kepadatan Jenis Vegetasi Mangrove Menurut
Tingkatan Pertumbuhan di Wilayah Pesisir Kabupaten Kolaka Provinsi Sulawesi Tenggara. Warta - Wiptek, 16(2):128-136.

Nugroho, A.W., 2013. Pengaruh Komposisi Media Tanam terhadap Pertumbuhan Awal Cemara Udang (Casuarina equisetifolia var. Incana) pada Gumuk Pasir Pantai. Indonesian Forest Rehabilitation Journal, 1(1):113-125.

Nurjanto, H.H., Suhardi, dan Djulianto, S., 2009. Tanggapan Semai Cemara Udang (Casuarinaequisetifolia var. Incana) Terhadap Cekaman Salinitas dan Frekuensi Penyiraman Padamedia Pasir Pantai. Prosiding seminar nasional Silvikultur Rehabilitasi Lahan: Pengembangan Strategi untuk Mengendalikan Tingginya Laju Degradasi Hutan. Yogyakarta, 24-25 November 2008,pp. 176-183.

Nybakken, J. W. 1992. Biologi Laut Suatu Pendekatan Ekologis. PT Gramedia. Jakarta.

Onrizal dan Kusmana, C., 2008. Studi Ekologi Hutan Mangrove di Pantai Timur Sumatera Utara. Biodiversitas, 9(1):25-29.

Poedjirahajoe, E., 2007. Dendrogram Zonasi Pertumbuhan Mangrove Berdasarkan Habitatnnya di Kawasan Rehabilitasi Pantai Utara Jawa Tengah Bagian Barat. Jurnal Ilmu Kehutanan, 1(2):10-21.

Prabakaran, K., dan Britto, S.J., 2012. Biology, Agroforestry and Medicinal Value of Callophyllum inophyllum L. (Clusiacea): AReview. International Journal of Natural Product Research, I(2):24-33.

Primavera, J.H., 1998. Tropical Shrimp Farming and Its Sustainability. In: de Silva, S. (ed.), Tropical Mariculture. Academic Press. London.

Rahayu, Ariyanto, D.P., Komariah, Hartati, S., Syamsiyah, J., dan Dewi, W.S., 2014. Dampak Erupsi Gunung Merapi Terhadap Lahan dan Upaya-upaya Pemulihannya. Jurnal IImu IImu Pertanian, 19(1):61-72.

Setyawan, A.D., Susilowati, A., dan Wiryanto, 2002. Habitat Reliks Vegetasi Mangrove di Pantai Selatan Jawa. Biodiversitas, 3(2):242256.

Singh, Y.P., Singh, G., dan Sharma, D.K., 2011. Ameliorative Effect of Multipurpose Tree Species Grown on Sodic Soils of Indogangetic Alluvial Plains of India. Arid Land Research and Management, 25(1):55-74.

Suhardi, Sutikno, Nurjanto, H.H., dan Widodo, M.A., 2002. Casuarina equisetifolia Plantingfor Rehabilitation of Coastal Sand Dune Area. Proceedings of The 11th International Workshop of Bio-Refor. Seoul, 
Korea, 8-12 October 2002, pp. 143-150. Seoul.

Sukri, dan Yeni, S., 2016. Sistem Informasi Geografis Budidaya Ikan Lele di Kawasan Wisata Kampung Lele Kampar Riau. Jurnal Teknologi dan Sistem Informasi UNIVRAB, 1(1):2477-2062.

Sumardi, 2008. Model Rehabilitasi Kawasan Pantai. Seminar Nasional Silvikultur Rehabilitasi Lahan : Pengembangan Strategi untuk Mengendalikan Tingginya Laju Degradasi Hutan, Wanagama I, 24-25 November 2008. Yogyakarta.

Supriharyono, 2000. Pelestarian dan Pengelolaan Sumber Daya Alam di Wilayah Pesisir Tropis. PT Gramedia Pustaka Utama. Jakarta.
Thuy, N., Tanaka, N., dan Tanimoto, K., 2012. Tsunami Mitigation by Coastal Vegetation Considering The Effect of Tree Breaking. Journal of Coastal Conservation, 16(1):111121.

Wahyuningsih, E.P., Suleman, S.M., dan Ramadanil, 2012. Struktur dan Komposisi Vegetasi Mangrove di Desa Lalombi Kecamatan Banawa Selatan Kabupaten Donggala. Jurnal Biocelebes, 6(2):84-100.

Wibowo, M., 2002. Sistem Jaringan Kelembagaan dalam Pengelolaan Lingkungan Pantai. Jurnal Teknologi Lingkungan, 3(3):218-225. 